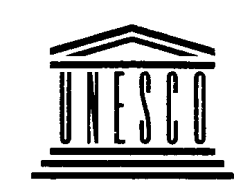

CONVENTION FOR THE SAFEGUARDING OF THE INTANGIBLE CULTURAL HERITAGE

Paris, 17 October 2003 


\section{CONVENTION FOR THE SAFEGUARDING OF THE INTANGIBLE CULTURAL HERITAGE}

The General Conference of the United Nations Educational, Scientific and Cultural Organization hereinafter referred to as UNESCO, meeting in Paris, from 29 September to 17 October 2003, at its 32nd session,

Referring to existing international human rights instruments, in particular to the Universal Declaration on Human Rights of 1948, the International Covenant on Economic, Social and Cultural Rights of 1966, and the International Covenant on Civil and Political Rights of 1966,

Considering the importance of the intangible cultural heritage as a mainspring of cultural diversity and a guarantee of sustainable development, as underscored in the UNESCO Recommendation on the Safeguarding of Traditional Culture and Folklore of 1989, in the UNESCO Universal Declaration on Cultural Diversity of 2001, and in the Istanbul Declaration of 2002 adopted by the Third Round Table of Ministers of Culture,

Considering the deep-seated interdependence between the intangible cultural heritage and the tangible cultural and natural heritage,

Recognizing that the processes of globalization and social transformation, alongside the conditions they create for renewed dialogue among communities, also give rise, as does the phenomenon of intolerance, to grave threats of deterioration, disappearance and destruction of the intangible cultural heritage, in particular owing to a lack of resources for safeguarding such heritage,

Being aware of the universal will and the common concern to safeguard the intangible cultural heritage of humanity,

Recognizing that communities, in particular indigenous communities, groups and, in some cases, individuals, play an important role in the production, safeguarding, maintenance and recreation of the intangible cultural heritage, thus helping to enrich cultural diversity and human creativity,

Noting the far-reaching impact of the activities of UNESCO in establishing normative instruments for the protection of the cultural heritage, in particular the Convention for the Protection of the World Cultural and Natural Heritage of 1972,

Noting further that no binding multilateral instrument as yet exists for the safeguarding of the intangible cultural heritage,

Considering that existing international agreements, recommendations and resolutions concerning the cultural and natural heritage need to be effectively enriched and supplemented by means of new provisions relating to the intangible cultural heritage,

Considering the need to build greater awareness, especially among the younger generations, of the importance of the intangible cultural heritage and of its safeguarding,

Considering that the international community should contribute, together with the States Parties to this Convention, to the safeguarding of such heritage in a spirit of cooperation and mutual assistance, 
Recalling UNESCO's programmes relating to the intangible cultural heritage, in particular the Proclamation of Masterpieces of the Oral and Intangible Heritage of Humanity,

Considering the invaluable role of the intangible cultural heritage as a factor in bringing human beings closer together and ensuring exchange and understanding among them,

Adopts this Convention on this seventeenth day of October 2003.

\section{General provisions}

\section{Article 1-Purposes of the Convention}

The purposes of this Convention are:

(a) to safeguard the intangible cultural heritage;

(b) to ensure respect for the intangible cultural heritage of the communities, groups and individuals concerned;

(c) to raise awareness at the local, national and international levels of the importance of the intangible cultural heritage, and of ensuring mutual appreciation thereof;

(d) to provide for international cooperation and assistance.

\section{Article 2-Definitions}

For the purposes of this Convention,

1. The "intangible cultural heritage" means the practices, representations, expressions, knowledge, skills - as well as the instruments, objects, artefacts and cultural spaces associated therewith - that communities, groups and, in some cases, individuals recognize as part of their cultural heritage. This intangible cultural heritage, transmitted from generation to generation, is constantly recreated by communities and groups in response to their environment, their interaction with nature and their history, and provides them with a sense of identity and continuity, thus promoting respect for cultural diversity and human creativity. For the purposes of this Convention, consideration will be given solely to such intangible cultural heritage as is compatible with existing international human rights instruments, as well as with the requirements of mutual respect among communities, groups and individuals, and of sustainable development.

2. The "intangible cultural heritage", as defined in paragraph 1 above, is manifested inter alia in the following domains:

(a) oral traditions and expressions, including language as a vehicle of the intangible cultural heritage;

(b) performing arts;

(c) social practices, rituals and festive events;

(d) knowledge and practices concerning nature and the universe;

(e) traditional craftsmanship. 
3. "Safeguarding" means measures aimed at ensuring the viability of the intangible cultural heritage, including the identification, documentation, research, preservation, protection, promotion, enhancement, transmission, particularly through formal and nonformal education, as well as the revitalization of the various aspects of such heritage.

4. "States Parties" means States which are bound by this Convention and among which this Convention is in force.

5. This Convention applies mutatis mutandis to the territories referred to in Article 33 which become Parties to this Convention in accordance with the conditions set out in that Article. To that extent the expression "States Parties" also refers to such territories.

\section{Article 3 - Relationship to other international instruments}

Nothing in this Convention may be interpreted as:

(a) altering the status or diminishing the level of protection under the 1972 Convention concerning the Protection of the World Cultural and Natural Heritage of World Heritage properties with which an item of the intangible cultural heritage is directly associated; or

(b) affecting the rights and obligations of States Parties deriving from any international instrument relating to intellectual property rights or to the use of biological and ecological resources to which they are parties.

\section{Organs of the Convention}

\section{Article 4-General Assembly of the States Parties}

1. A General Assembly of the States Parties is hereby established, hereinafter referred to as "the General Assembly". The General Assembly is the sovereign body of this Convention.

2. The General Assembly shall meet in ordinary session every two years. It may meet in extraordinary session if it so decides or at the request either of the Intergovernmental Committee for the Safeguarding of the Intangible Cultural Heritage or of at least one-third of the States Parties.

3. The General Assembly shall adopt its own Rules of Procedure.

\section{Article 5 - Intergovernmental Committee for the Safeguarding of the Intangible Cultural Heritage}

1. An Intergovernmental Committee for the Safeguarding of the Intangible Cultural Heritage, hereinafter referred to as "the Committee", is hereby established within UNESCO. It shall be composed of representatives of 18 States Parties, elected by the States Parties meeting in General Assembly, once this Convention enters into force in accordance with Article 34.

2. The number of States Members of the Committee shall be increased to 24 once the number of the States Parties to the Convention reaches 50. 
Article 6-Election and terms of office of States Members of the Committee

1. The election of States Members of the Committee shall obey the principles of equitable geographical representation and rotation.

2. States Members of the Committee shall be elected for a term of four years by States Parties to the Convention meeting in General Assembly.

3. However, the term of office of half of the States Members of the Committee elected at the first election is limited to two years. These States shall be chosen by lot at the first election.

4. Every two years, the General Assembly shall renew half of the States Members of the Committee.

5. It shall also elect as many States Members of the Committee as required to fill vacancies.

6. A State Member of the Committee may not be elected for two consecutive terms.

7. States Members of the Committee shall choose as their representatives persons who are qualified in the various fields of the intangible cultural heritage.

\section{Article 7 - Functions of the Committee}

Without prejudice to other prerogatives granted to it by this Convention, the functions of the Committee shall be to:

(a) promote the objectives of the Convention, and to encourage and monitor the implementation thereof;

(b) provide guidance on best practices and make recommendations on measures for the safeguarding of the intangible cultural heritage;

(c) prepare and submit to the General Assembly for approval a draft plan for the use of the resources of the Fund, in accordance with Article 25;

(d) seek means of increasing its resources, and to take the necessary measures to this end, in accordance with Article 25;

(e) prepare and submit to the General Assembly for approval operational directives for the implementation of this Convention;

(f) examine, in accordance with Article 29, the reports submitted by States Parties, and to summarize them for the General Assembly;

(g) examine requests submitted by States Parties, and to decide thereon, in accordance with objective selection criteria to be established by the Committee and approved by the General Assembly for: 
(i) inscription on the lists and proposals mentioned under Articles 16, 17 and 18 ;

(ii) the granting of international assistance in accordance with Article 22.

\section{Article 8 - Working methods of the Committee}

1. The Committee shall be answerable to the General Assembly. It shall report to it on all its activities and decisions.

2. The Committee shall adopt its own Rules of Procedure by a two-thirds majority of its Members.

3. The Committee may establish, on a temporary basis, whatever ad hoc consultative bodies it deems necessary to carry out its task.

4. The Committee may invite to its meetings any public or private bodies, as well as private persons, with recognized competence in the various fields of the intangible cultural heritage, in order to consult them on specific matters.

\section{Article 9 - Accreditation of advisory organizations}

1. The Committee shall propose to the General Assembly the accreditation of nongovernmental organizations with recognized competence in the field of the intangible cultural heritage to act in an advisory capacity to the Committee.

2. The Committee shall also propose to the General Assembly the criteria for and modalities of such accreditation.

\section{Article 10 - The Secretariat}

1. The Committee shall be assisted by the UNESCO Secretariat.

2. The Secretariat shall prepare the documentation of the General Assembly and of the Committee, as well as the draft agenda of their meetings, and shall ensure the implementation of their decisions.

\section{Safeguarding of the intangible cultural heritage at the national level}

\section{Article 11 - Role of States Parties}

Each State Party shall:

(a) take the necessary measures to ensure the safeguarding of the intangible cultural heritage present in its territory;

(b) among the safeguarding measures referred to in Article 2, paragraph 3, identify and define the various elements of the intangible cultural heritage present in its territory, with the participation of communities, groups and relevant nongovernmental organizations. 
1. To ensure identification with a view to safeguarding, each State Party shall draw up, in a manner geared to its own situation, one or more inventories of the intangible cultural heritage present in its territory. These inventories shall be regularly updated.

2. When each State Party periodically submits its report to the Committee, in accordance with Article 29, it shall provide relevant information on such inventories.

\section{Article 13 - Other measures for safeguarding}

To ensure the safeguarding, development and promotion of the intangible cultural heritage present in its territory, each State Party shall endeavour to:

(a) adopt a general policy aimed at promoting the function of the intangible cultural heritage in society, and at integrating the safeguarding of such heritage into planning programmes;

(b) designate or establish one or more competent bodies for the safeguarding of the intangible cultural heritage present in its territory;

(c) foster scientific, technical and artistic studies, as well as research methodologies, with a view to effective safeguarding of the intangible cultural heritage, in particular the intangible cultural heritage in danger;

(d) adopt appropriate legal, technical, administrative and financial measures aimed at:

(i) fostering the creation or strengthening of institutions for training in the management of the intangible cultural heritage and the transmission of such heritage through forums and spaces intended for the performance or expression thereof;

(ii) ensuring access to the intangible cultural heritage while respecting customary practices governing access to specific aspects of such heritage;

(iii) establishing documentation institutions for the intangible cultural heritage and facilitating access to them.

Article 14 - Education, awareness-raising and capacity-building

Each State Party shall endeavour, by all appropriate means, to:

(a) ensure recognition of, respect for, and enhancement of the intangible cultural heritage in society, in particular through:

(i) educational, awareness-raising and information programmes, aimed at the general public, in particular young people;

(ii) specific educational and training programmes within the communities and groups concerned; 
(iii) capacity-building activities for the safeguarding of the intangible cultural heritage, in particular management and scientific research; and

(iv) non-formal means of transmitting knowledge;

(b) keep the public informed of the dangers threatening such heritage, and of the activities carried out in pursuance of this Convention;

(c) promote education for the protection of natural spaces and places of memory whose existence is necessary for expressing the intangible cultural heritage.

Article 15 - Participation of communities, groups and individuals

Within the framework of its safeguarding activities of the intangible cultural heritage, each State Party shall endeavour to ensure the widest possible participation of communities, groups and, where appropriate, individuals that create, maintain and transmit such heritage, and to involve them actively in its management.

\section{Safeguarding of the intangible cultural heritage at the international level}

\section{Article 16 - Representative List of the Intangible Cultural Heritage of Humanity}

1. In order to ensure better visibility of the intangible cultural heritage and awareness of its significance, and to encourage dialogue which respects cultural diversity, the Committee, upon the proposal of the States Parties concerned, shall establish, keep up to date and publish a Representative List of the Intangible Cultural Heritage of Humanity.

2. The Committee shall draw up and submit to the General Assembly for approval the criteria for the establishment, updating and publication of this Representative List.

\section{Article 17 - List of Intangible Cultural Heritage in Need of Urgent Safeguarding}

1. With a view to taking appropriate safeguarding measures, the Committee shall establish, keep up to date and publish a List of Intangible Cultural Heritage in Need of Urgent Safeguarding, and shall inscribe such heritage on the List at the request of the State Party concerned.

2. The Committee shall draw up and submit to the General Assembly for approval the criteria for the establishment, updating and publication of this List.

3. In cases of extreme urgency - the objective criteria of which shall be approved by the General Assembly upon the proposal of the Committee - the Committee may inscribe an item of the heritage concerned on the List mentioned in paragraph 1, in consultation with the State Party concerned.

\section{Article 18 - Programmes, projects and activities for the safeguarding of the intangible cultural heritage}

1. On the basis of proposals submitted by States Parties, and in accordance with criteria to be defined by the Committee and approved by the General Assembly, the Committee shall periodically select and promote national, subregional and regional programmes, projects and 
activities for the safeguarding of the heritage which it considers best reflect the principles and objectives of this Convention, taking into account the special needs of developing countries.

2. To this end, it shall receive, examine and approve requests for international assistance from States Parties for the preparation of such proposals.

3. The Committee shall accompany the implementation of such projects, programmes and activities by disseminating best practices using means to be determined by it.

\section{International cooperation and assistance}

\section{Article 19-Cooperation}

1. For the purposes of this Convention, international cooperation includes, inter alia, the exchange of information and experience, joint initiatives, and the establishment of a mechanism of assistance to States Parties in their efforts to safeguard the intangible cultural heritage.

2. Without prejudice to the provisions of their national legislation and customary law and practices, the States Parties recognize that the safeguarding of intangible cultural heritage is of general interest to humanity, and to that end undertake to cooperate at the bilateral, subregional, regional and international levels.

\section{Article 20 - Purposes of international assistance}

International assistance may be granted for the following purposes:

(a) the safeguarding of the heritage inscribed on the List of Intangible Cultural Heritage in Need of Urgent Safeguarding;

(b) the preparation of inventories in the sense of Articles 11 and 12;

(c) support for programmes, projects and activities carried out at the national, subregional and regional levels aimed at the safeguarding of the intangible cultural heritage;

(d) any other purpose the Committee may deem necessary.

\section{Article 21 - Forms of international assistance}

The assistance granted by the Committee to a State Party shall be governed by the operational directives foreseen in Article 7 and by the agreement referred to in Article 24, and may take the following forms:
(a) studies concerning various aspects of safeguarding;
(b) the provision of experts and practitioners;
(c) the training of all necessary staff;
(d) the elaboration of standard-setting and other measures; 
(e) the creation and operation of infrastructures;

(f) the supply of equipment and know-how;

(g) other forms of financial and technical assistance, including, where appropriate, the granting of low-interest loans and donations.

Article 22 - Conditions governing international assistance

1. The Committee shall establish the procedure for examining requests for international assistance, and shall specify what information shall be included in the requests, such as the measures envisaged and the interventions required, together with an assessment of their cost.

2. In emergencies, requests for assistance shall be examined by the Committee as a matter of priority.

3. In order to reach a decision, the Committee shall undertake such studies and consultations as it deems necessary.

\section{Article 23 - Requests for international assistance}

1. Each State Party may submit to the Committee a request for international assistance for the safeguarding of the intangible cultural heritage present in its territory.

2. Such a request may also be jointly submitted by two or more States Parties.

3. The request shall include the information stipulated in Article 22, paragraph 1, together with the necessary documentation.

\section{Article 24 - Role of beneficiary States Parties}

1. In conformity with the provisions of this Convention, the international assistance granted shall be regulated by means of an agreement between the beneficiary State Party and the Committee.

2. As a general rule, the beneficiary State Party shall, within the limits of its resources, share the cost of the safeguarding measures for which international assistance is provided.

3. The beneficiary State Party shall submit to the Committee a report on the use made of the assistance provided for the safeguarding of the intangible cultural heritage.

\section{Intangible Cultural Heritage Fund}

\section{Article 25 - Nature and resources of the Fund}

1. A "Fund for the Safeguarding of the Intangible Cultural Heritage", hereinafter referred to as "the Fund", is hereby established.

2. The Fund shall consist of funds-in-trust established in accordance with the Financial Regulations of UNESCO. 
3. The resources of the Fund shall consist of:

(a) contributions made by States Parties;

(b) funds appropriated for this purpose by the General Conference of UNESCO;

(c) contributions, gifts or bequests which may be made by:

(i) other States;

(ii) organizations and programmes of the United Nations system, particularly the United Nations Development Programme, as well as other international organizations;

(iii) public or private bodies or individuals;

(d) any interest due on the resources of the Fund;

(e) funds raised through collections, and receipts from events organized for the benefit of the Fund;

(f) any other resources authorized by the Fund's regulations, to be drawn up by the Committee.

4. The use of resources by the Committee shall be decided on the basis of guidelines laid down by the General Assembly.

5. The Committee may accept contributions and other forms of assistance for general and specific purposes relating to specific projects, provided that those projects have been approved by the Committee.

6. No political, economic or other conditions which are incompatible with the objectives of this Convention may be attached to contributions made to the Fund.

\section{Article 26-Contributions of States Parties to the Fund}

1. Without prejudice to any supplementary voluntary contribution, the States Parties to this Convention undertake to pay into the Fund, at least every two years, a contribution, the amount of which, in the form of a uniform percentage applicable to all States, shall be determined by the General Assembly. This decision of the General Assembly shall be taken by a majority of the States Parties present and voting which have not made the declaration referred to in paragraph 2 of this Article. In no case shall the contribution of the State Party exceed $1 \%$ of its contribution to the regular budget of UNESCO.

2. However, each State referred to in Article 32 or in Article 33 of this Convention may declare, at the time of the deposit of its instruments of ratification, acceptance, approval or accession, that it shall not be bound by the provisions of paragraph 1 of this Article.

3. A State Party to this Convention which has made the declaration referred to in paragraph 2 of this Article shall endeavour to withdraw the said declaration by notifying the Director-General of UNESCO. However, the withdrawal of the declaration shall not take 
effect in regard to the contribution due by the State until the date on which the subsequent session of the General Assembly opens.

4. In order to enable the Committee to plan its operations effectively, the contributions of States Parties to this Convention which have made the declaration referred to in paragraph 2 of this Article shall be paid on a regular basis, at least every two years, and should be as close as possible to the contributions they would have owed if they had been bound by the provisions of paragraph 1 of this Article.

5. Any State Party to this Convention which is in arrears with the payment of its compulsory or voluntary contribution for the current year and the calendar year immediately preceding it shall not be eligible as a Member of the Committee; this provision shall not apply to the first election. The term of office of any such State which is already a Member of the Committee shall come to an end at the time of the elections provided for in Article 6 of this Convention.

\section{Article 27 - Voluntary supplementary contributions to the Fund}

States Parties wishing to provide voluntary contributions in addition to those foreseen under Article 26 shall inform the Committee, as soon as possible, so as to enable it to plan its operations accordingly.

\section{Article 28 - International fund-raising campaigns}

The States Parties shall, insofar as is possible, lend their support to international fund-raising campaigns organized for the benefit of the Fund under the auspices of UNESCO.

\section{Reports}

Article 29 - Reports by the States Parties

The States Parties shall submit to the Committee, observing the forms and periodicity to be defined by the Committee, reports on the legislative, regulatory and other measures taken for the implementation of this Convention.

\section{Article 30 - Reports by the Committee}

1. On the basis of its activities and the reports by States Parties referred to in Article 29, the Committee shall submit a report to the General Assembly at each of its sessions.

2. The report shall be brought to the attention of the General Conference of UNESCO.

\section{Transitional clause}

\section{Article 31 -Relationship to the Proclamation of Masterpieces of the Oral and Intangible Heritage of Humanity}

1. The Committee shall incorporate in the Representative List of the Intangible Cultural Heritage of Humanity the items proclaimed "Masterpieces of the Oral and Intangible Heritage of Humanity" before the entry into force of this Convention. 
2. The incorporation of these items in the Representative List of the Intangible Cultural Heritage of Humanity shall in no way prejudge the criteria for future inscriptions decided upon in accordance with Article 16, paragraph 2.

3. No further Proclamation will be made after the entry into force of this Convention.

\section{Final clauses}

\section{Article 32 - Ratification, acceptance or approval}

1. This Convention shall be subject to ratification, acceptance or approval by States Members of UNESCO in accordance with their respective constitutional procedures.

2. The instruments of ratification, acceptance or approval shall be deposited with the Director-General of UNESCO.

\section{Article 33 - Accession}

1. This Convention shall be open to accession by all States not Members of UNESCO that are invited by the General Conference of UNESCO to accede to it.

2. This Convention shall also be open to accession by territories which enjoy full internal self-government recognized as such by the United Nations, but have not attained full independence in accordance with General Assembly resolution 1514 (XV), and which have competence over the matters governed by this Convention, including the competence to enter into treaties in respect of such matters.

3. The instrument of accession shall be deposited with the Director-General of UNESCO.

\section{Article 34 - Entry into force}

This Convention shall enter into force three months after the date of the deposit of the thirtieth instrument of ratification, acceptance, approval or accession, but only with respect to those States that have deposited their respective instruments of ratification, acceptance, approval, or accession on or before that date. It shall enter into force with respect to any other State Party three months after the deposit of its instrument of ratification, acceptance, approval or accession.

\section{Article 35 - Federal or non-unitary constitutional systems}

The following provisions shall apply to States Parties which have a federal or non-unitary constitutional system:

(a) with regard to the provisions of this Convention, the implementation of which comes under the legal jurisdiction of the federal or central legislative power, the obligations of the federal or central government shall be the same as for those States Parties which are not federal States;

(b) with regard to the provisions of this Convention, the implementation of which comes under the jurisdiction of individual constituent States, countries, provinces or cantons which are not obliged by the constitutional system of the federation to 
take legislative measures, the federal government shall inform the competent authorities of such States, countries, provinces or cantons of the said provisions, with its recommendation for their adoption.

\section{Article 36 - Denunciation}

\section{Each State Party may denounce this Convention.}

2. The denunciation shall be notified by an instrument in writing, deposited with the Director-General of UNESCO.

3. The denunciation shall take effect twelve months after the receipt of the instrument of denunciation. It shall in no way affect the financial obligations of the denouncing State Party until the date on which the withdrawal takes effect.

\section{Article 37 - Depositary functions}

The Director-General of UNESCO, as the Depositary of this Convention, shall inform the States Members of the Organization, the States not Members of the Organization referred to in Article 33, as well as the United Nations, of the deposit of all the instruments of ratification, acceptance, approval or accession provided for in Articles 32 and 33, and of the denunciations provided for in Article 36.

\section{Article $38-$ Amendments}

1. A State Party may, by written communication addressed to the Director-General, propose amendments to this Convention. The Director-General shall circulate such communication to all States Parties. If, within six months from the date of the circulation of the communication, not less than one half of the States Parties reply favourably to the request, the Director-General shall present such proposal to the next session of the General Assembly for discussion and possible adoption.

2. Amendments shall be adopted by a two-thirds majority of States Parties present and voting.

3. Once adopted, amendments to this Convention shall be submitted for ratification, acceptance, approval or accession to the States Parties.

4. Amendments shall enter into force, but solely with respect to the States Parties that have ratified, accepted, approved or acceded to them, three months after the deposit of the instruments referred to in paragraph 3 of this Article by two-thirds of the States Parties. Thereafter, for each State Party that ratifies, accepts, approves or accedes to an amendment, the said amendment shall enter into force three months after the date of deposit by that State Party of its instrument of ratification, acceptance, approval or accession.

5. The procedure set out in paragraphs 3 and 4 shall not apply to amendments to Article 5 concerning the number of States Members of the Committee. These amendments shall enter into force at the time they are adopted. 
6. A State which becomes a Party to this Convention after the entry into force of amendments in conformity with paragraph 4 of this Article shall, failing an expression of different intention, be considered:

(a) as a Party to this Convention as so amended; and

(b) as a Party to the unamended Convention in relation to any State Party not bound by the amendments.

\section{Article 39 - Authoritative texts}

This Convention has been drawn up in Arabic, Chinese, English, French, Russian and Spanish, the six texts being equally authoritative.

\section{Article 40 - Registration}

In conformity with Article 102 of the Charter of the United Nations, this Convention shall be registered with the Secretariat of the United Nations at the request of the Director-General of UNESCO. 